\title{
Sunflower in the global vegetable oil system: situation, specificities and perspectives ${ }^{\text {H }}$
}

\author{
Etienne Pilorgé* \\ Terres Inovia, Av L. Brétignières, F78850 Thiverval-Grignon, France
}

Received 6 March 2020 - Accepted 4 June 2020

\begin{abstract}
Sunflower is the third oilseed produced in the world, the fourth vegetable oil and third oilseed meal among protein feed sources. In the past decades, the competition has been tough on the very dynamic vegetable oils and oilseed meals markets, respectively driven by palm oil and soybean meal. The sunflower sector succeeded in maintaining its competitiveness through continuous innovation in genetics, cropping practices and research of added value leading to a higher market segmentation. This article establishes a picture of the past evolutions and present situation of the global sunflower sector and review potential development fields.
\end{abstract}

Keywords: Sunflower crop / economy / production / competitiveness / edible oil market / sunflower seeds markets

Résumé - Le tournesol dans le système mondial des huiles végétales : situation, spécificités et perspectives. Le tournesol est la troisième graine oléagineuse produite dans le monde, la quatrième huile végétale et le troisième tourteau oléagineux parmi les sources d'aliments protéiques. Au cours des dernières décennies, la concurrence a été rude sur les marchés très dynamiques des huiles végétales et des tourteaux d'oléagineux, tirés respectivement par l'huile de palme et le tourteau de soja. Le secteur du tournesol a réussi à maintenir sa compétitivité grâce à l'innovation continue dans la génétique, les pratiques culturales et la recherche de valeur ajoutée conduisant à une plus grande segmentation du marché. Cet article dresse un tableau des évolutions passées et de la situation actuelle du secteur mondial du tournesol et passe en revue les domaines de développement potentiels.

Mots clés : Culture du tournesol / économie / production / compétitivité / marché des huiles alimentaires / marché des graines de tournesol

\section{Global situation and dynamics of production}

The evolution of sunflower crop at global scale and over a long period is quite remarkable, going from 10 million tons for 9.6 million ha in 1975 to $52 \mathrm{MnT}$ for $27 \mathrm{Mha}$ in 2018: production grew twice as fast as acreage, reflecting both a dynamic market and sustained technical progress (Fig. 1).

Its seed contains around $44 \%$ oil and $16 \%$ proteins and sunflower is both an oil and protein species. It competes on both vegetable oils market, led by palm oil, and vegetable protein rich products (containing more than $15 \%$ proteins) market, driven by soybean.

From the world market point of view, sunflower is the third oilseed produced in the word, with $45 \mathrm{MnT}$ per year on

\footnotetext{
Contribution to the Topical Issue "Sunflower / Tournesol".

*Correspondence: e.pilorge@terresinovia.fr
}

the period 2014-2018, representing 9\% of the global oilseeds production, preceded by Soybean (60\%) and rapeseed (12\%) (Figs. 2 and 3). It comes in fourth position on vegetable oils market with $9.2 \%$ in $2017 / 18(19 \mathrm{MnT} /$ year), after Palm oil (36.5\%), Soybean oil (27.4\%) and rapeseed oil $(12.5 \%)$ on a total world production of $205 \mathrm{MnT}$ vegetable oils in 2017/18.

At last, it is the third oilseed meal, with $5.6 \%$ of the global production (20 MnT over $356 \mathrm{MnT})$, after Soybean meal $(66 \%)$ and rapeseed meal $(10 \%)$.

On the period 1975-2019, the global oilseeds production doubled every 20 years, and sunflower maintained a relatively constant share in the global oilseeds production, between 7 and $10 \%$ of the total, presently $9 \%$. But in the same time, soybean share progressed from 48 to $62 \%$ of the total, and rapeseed from 6 to $12 \%$. Most other species (cottonseed, groundnuts, ...) diminished in relative importance. It traduces a tendency towards a certain uniformization in the global production, and sunflower almost kept its position in this competition. 
Evolution of sunflowerseed World production (MnT, yellow bars) and acreage (Mn ha, red bars) 1976-2018

(source Oil World)

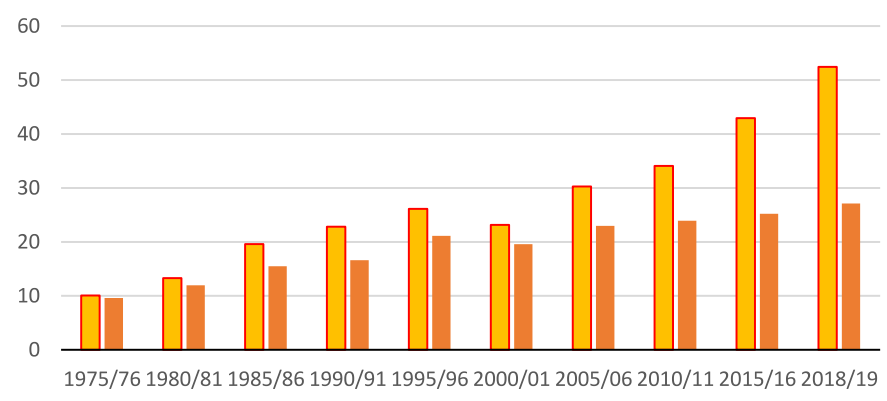

Fig. 1. Evolution of sunflower seed world production (Million Tons, yellow bars) and acreage (Million ha, red bars) 1976-2018 (Source: Oil World, 2019).
Evolution of the relative share of 10 oilseeds in global production (1975-2018)

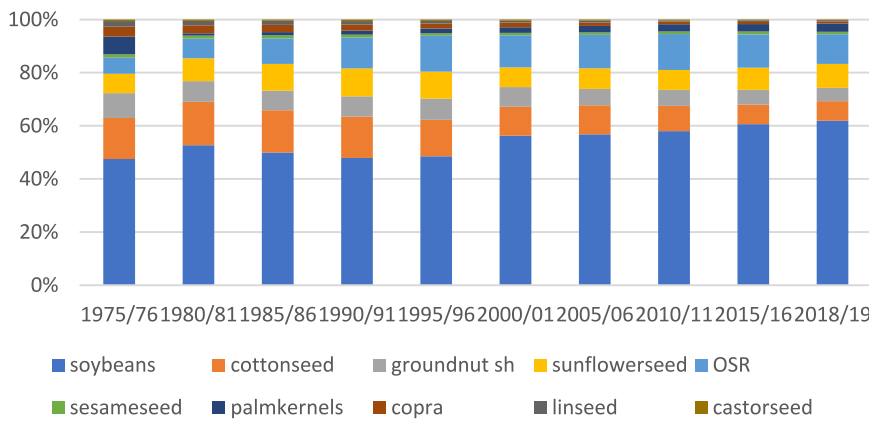

Fig. 3. Evolution of the relative share of 10 oilseeds in Global production (Source: Oil World, 2019).

\section{Evolution of oilseeds production 1975-2019 $\mathrm{MnT} / \mathrm{yr}$ (source Oilword)}

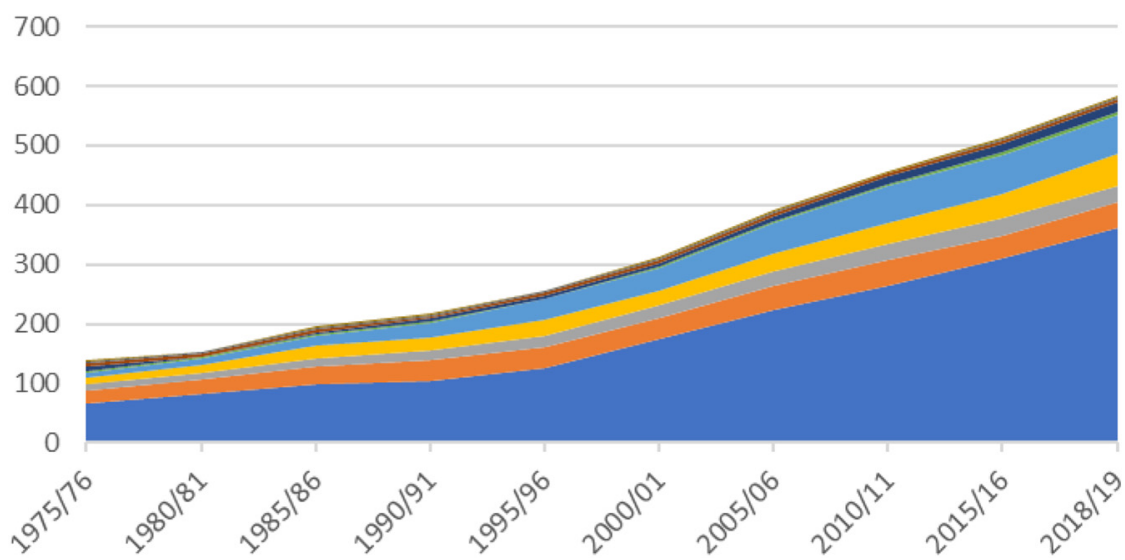

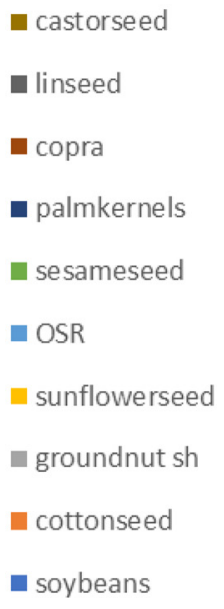

Fig. 2. Evolution of oilseeds production 1975-2019.

Sunflower is produced at large scale in a limited number of countries, and two thirds of the production are concentrated in Europe, including Ukraine and Russia and the Trakya region of Turkey. The other major producing countries are Argentina, China, United States, and the South-Eastern part of Africa (South Africa, Tanzania, Uganda, Zambia). The acreage was important in India, but dropped drastically from 2.35 in 2006 to 0.5 ten years later and $0.28 \mathrm{Mn}$ ha in 2019 (Fig. 4).

The top ten countries Ukraine, Federation of Russia, Argentina, China, Romania, Bulgaria, Turkey, Hungary, France and USA represent $84 \%$ of the production and $76 \%$ of the acreage on the 2014-2018 period. Considered as a single block, the European Union would come in third position after Ukraine and Russia. The ranking over two 5 years periods from 2009 to 2018 is almost stable except for France, which goes from rank 5 to rank 9, with both a drop in yield and acreage. The recent development of the production is quite impressive in the Eastern part of Europe and in Turkey (Tab. 1).

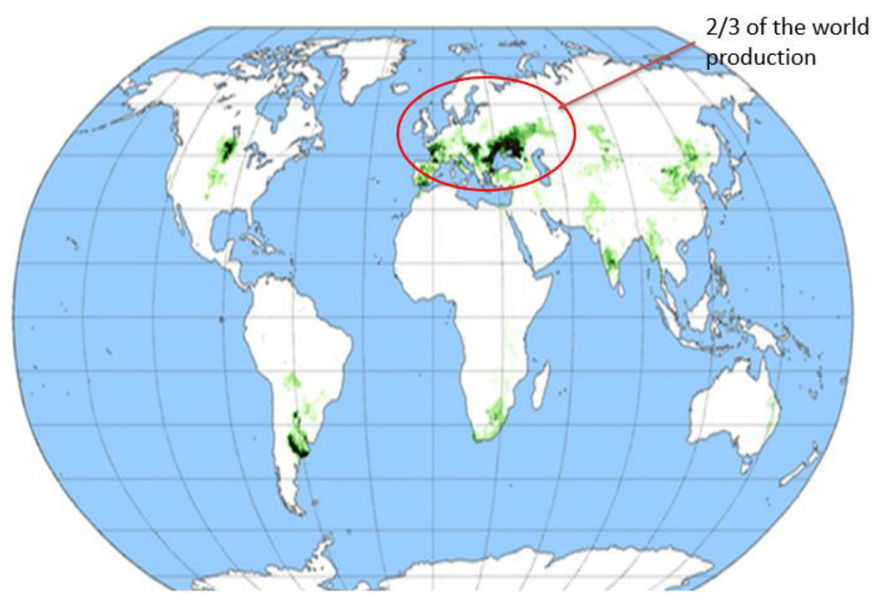

Fig. 4. Localisation of the sunflower production. 
Table 1. Acreage and production of top 10 countries.

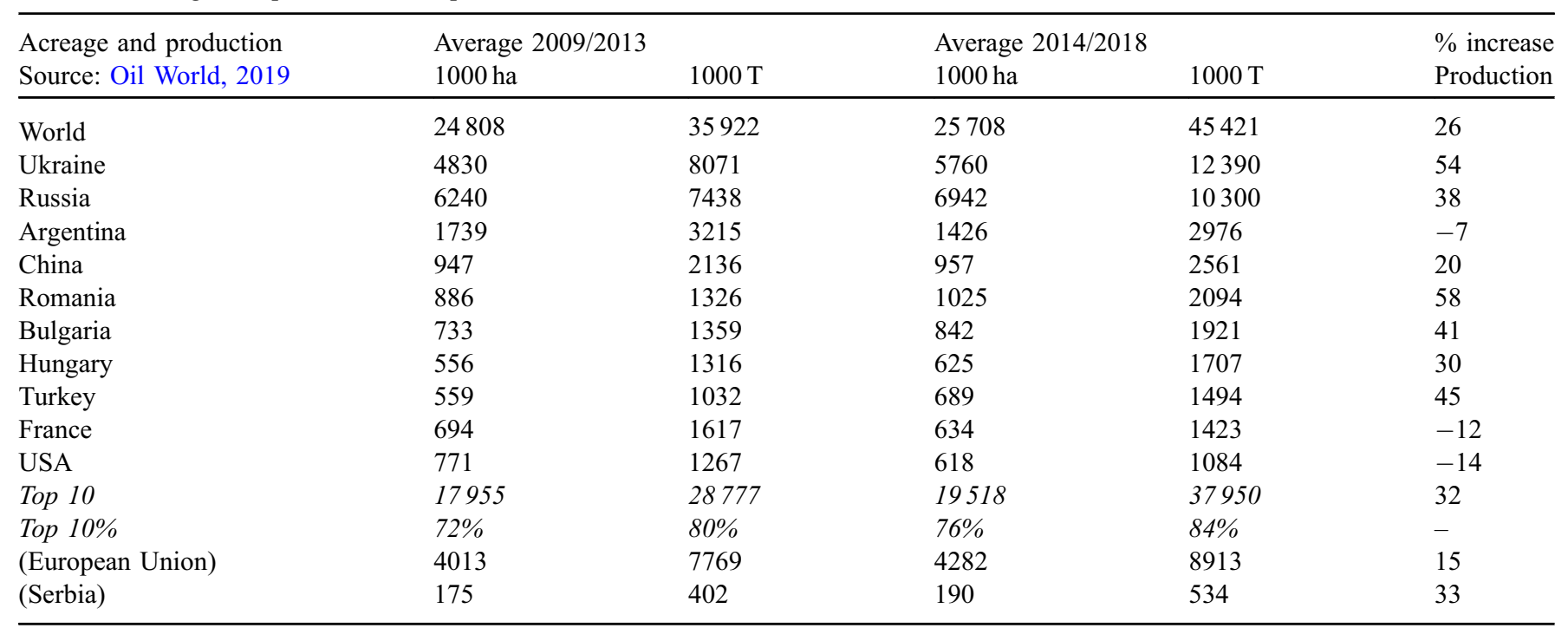

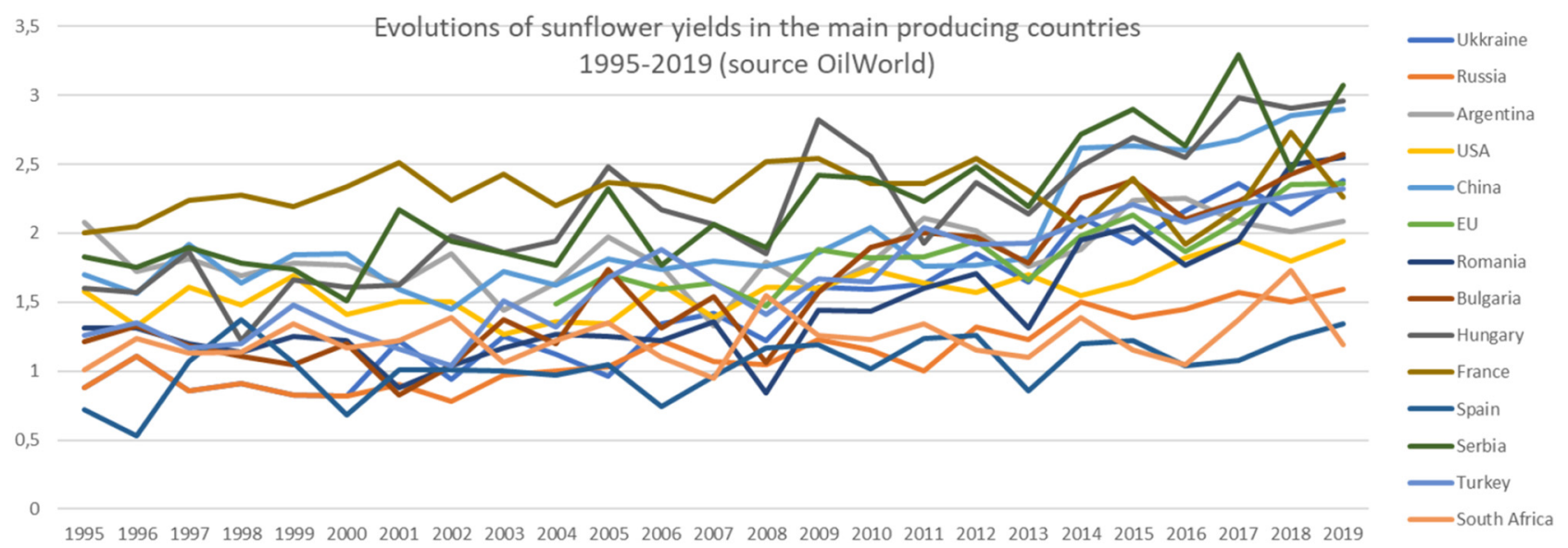

Fig. 5. Evolution of yields in the main sunflower producing countries 1995-2019.

The observation of yield evolutions in the main producing countries is quite instructive about the capacities of sunflower crop to keep the pace of global competition between oil and protein sources. The interannual variability of yields is quite important and tends to mask the tendencies (Fig. 5).

Using average yields over 5 years periods to smooth this variability (Fig. 6) permits to observe the real tendencies and distinguish 3 kinds of evolutions:

- Countries knowing a regular evolution since the early 2000 , most of them reaching now yields higher than $2 t / h a$, much higher than the average world level of $1.76 \mathrm{t} / \mathrm{ha}$ : in this category, we find the countries of the eastern part of Europe (Fig. 7);

- Countries with the same tendency, beginning a bit later, between 2008 and 2012: it includes Argentina, Bulgaria, China, reaching now more than $2 \mathrm{t} / \mathrm{ha}$ and, at a lesser extend USA (Fig. 8);

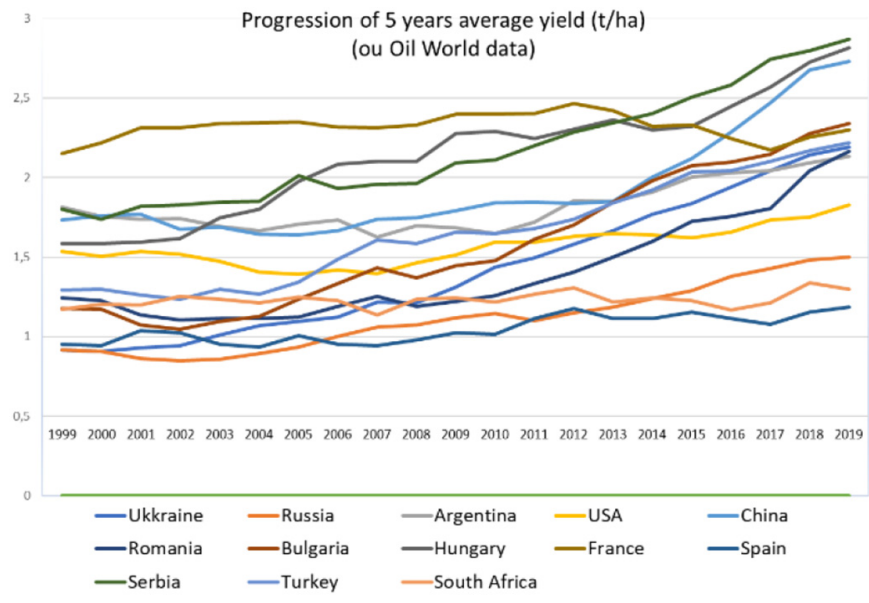

Fig. 6. Progression of 5 years average yield (t/ha) (Oil World, 2019 data). 


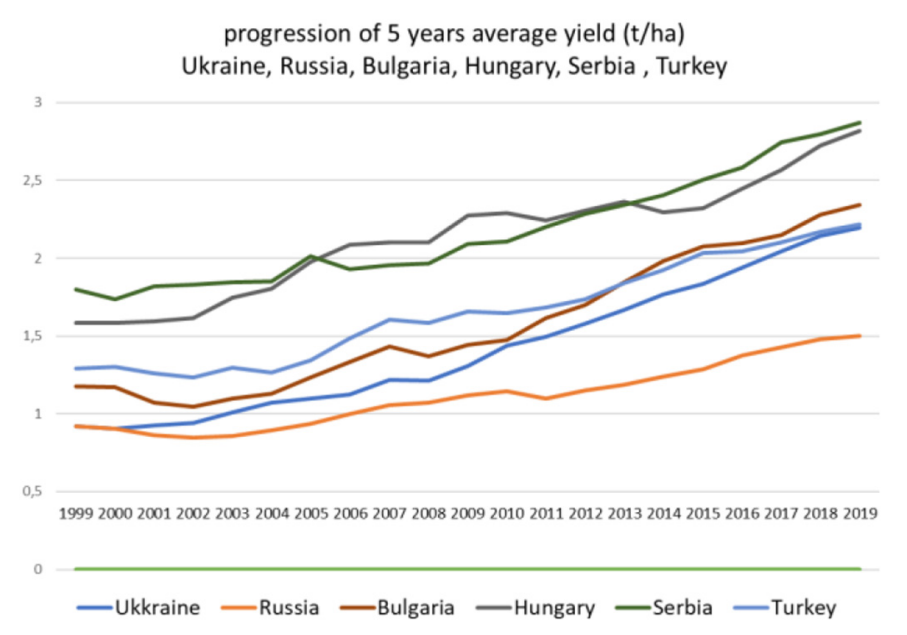

Fig. 7. Progression of 5 years average yield ( $t / h a)$ in Ukraine, Russia, Bulgaria, Hungary, Serbia, Turkey.

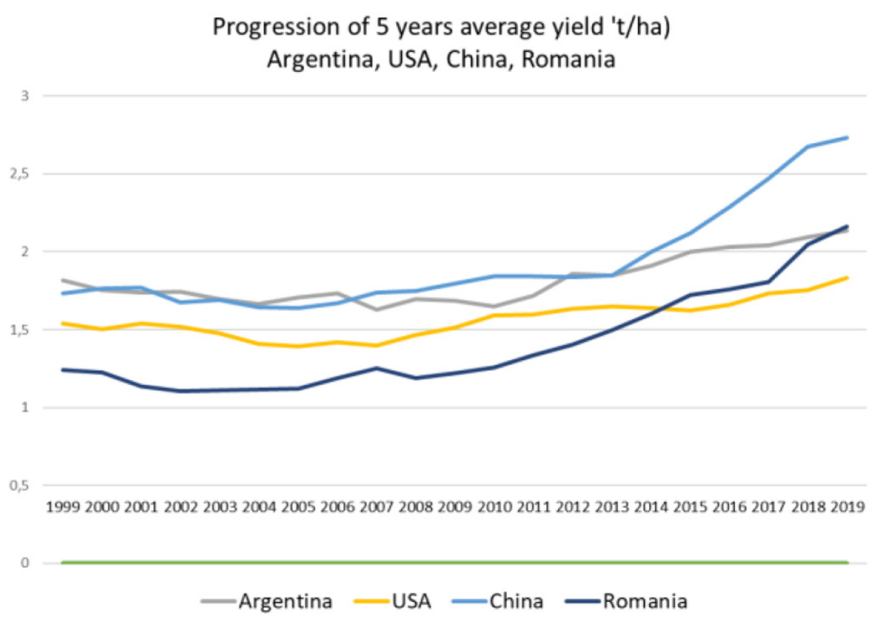

Fig. 8. Progression of 5 years average yield ( $t / h a)$ in Argentina, USA, China, Romania.

- Countries with flat curves or even decreasing: Spain and South Africa maintain between 1 and $1.3 \mathrm{t} / \mathrm{ha}$ probably constrained by pedoclimatic situations, and France shows a stagnation and even a decreasing tendency since 2012 (Fig. 9).

These tendencies for the first two categories certainly reflect changes in the improvement of cultivars, including the higher use of modern hybrids, and also improvements in cropping practices and should be analysed for each country.

In France, most sunflower (94\%) crops are grown in nonirrigated areas (only 6\% are irrigated according to Terres Inovia surveys), and thus face the climatic hazards in spring and summer seasons. A study by Sarron et al., 2016) comparing the periods 1989-1994 and 2015-2013 based on the crop model SUNFLO and surveys of agricultural practices concluded that the changes in the regional localisation of sunflower crops in France would not have affected significantly sunflower yields, but that shifts in agricultural practices

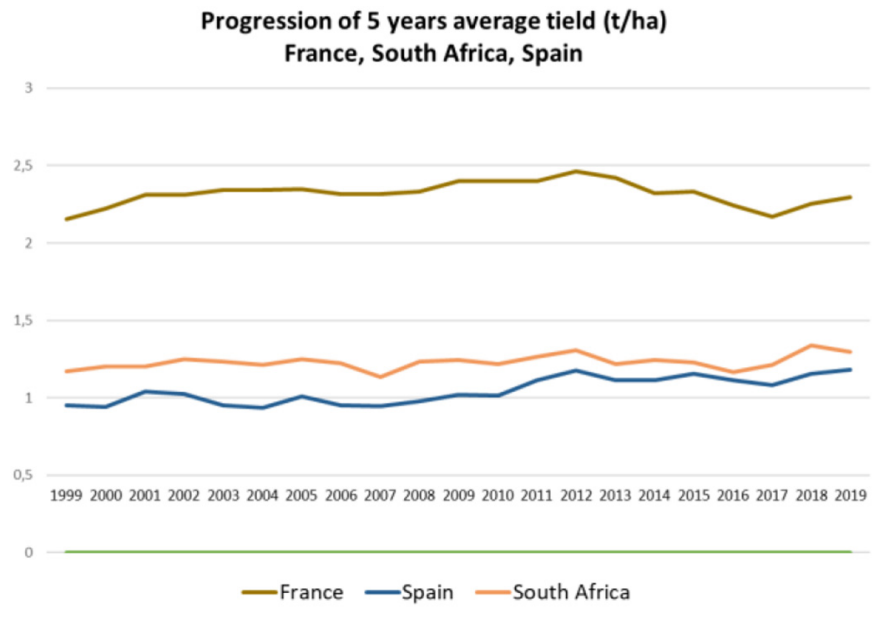

Fig. 9. Progression of 5 years average yield (t/ha) in France, South Africa, Spain.

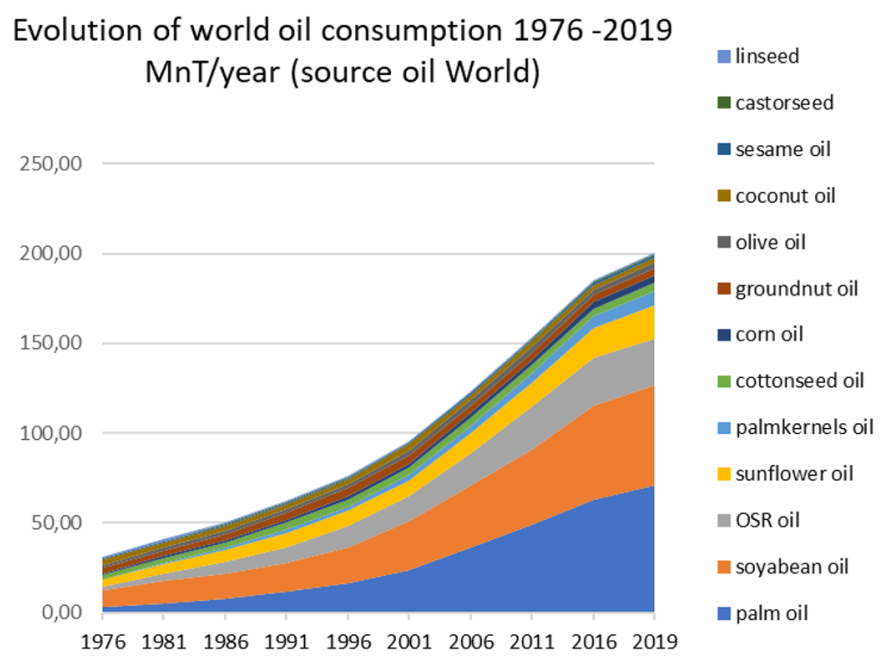

Fig. 10. Evolution of world oil consumption 1976-2019.

towards less input intensive practices would have affected negatively $(-0.03 \mathrm{t} / \mathrm{ha})$ when genetic progress would have raised yields by $0.48 \mathrm{t} / \mathrm{ha}$ and climate evolution on the period by $+0.06 \mathrm{t} / \mathrm{ha}$. The observed yield increment being $0.19 \mathrm{t} / \mathrm{ha}$, the yield gap evolution between these two periods is evaluated at $0.32 \mathrm{ha}$. Studies focussed on the assessment of genetic progress (Vear and Muller, 2011) also concluded that the progress in genetic potential has been maintained around $1 \% /$ year.

Shifts in agricultural practices seem to be, for the moment, a key explanatory factor of the yield evolutions, even if the role of climate and emerging pathogens have to be analysed too. For example, France has been knowing for some years some heavy macrofauna (mainly birds) attacks at crop settlement stages with consequences on plant densities, and sometimes the necessity to sow again ... or abandon the crop.

Furthermore, sunflower is traditionally a crop for which genetic resistances play a major role in the control of diseases and parasitic weeds: the durability of yield progress is also largely dependent on breeding effort on qualitative traits. 


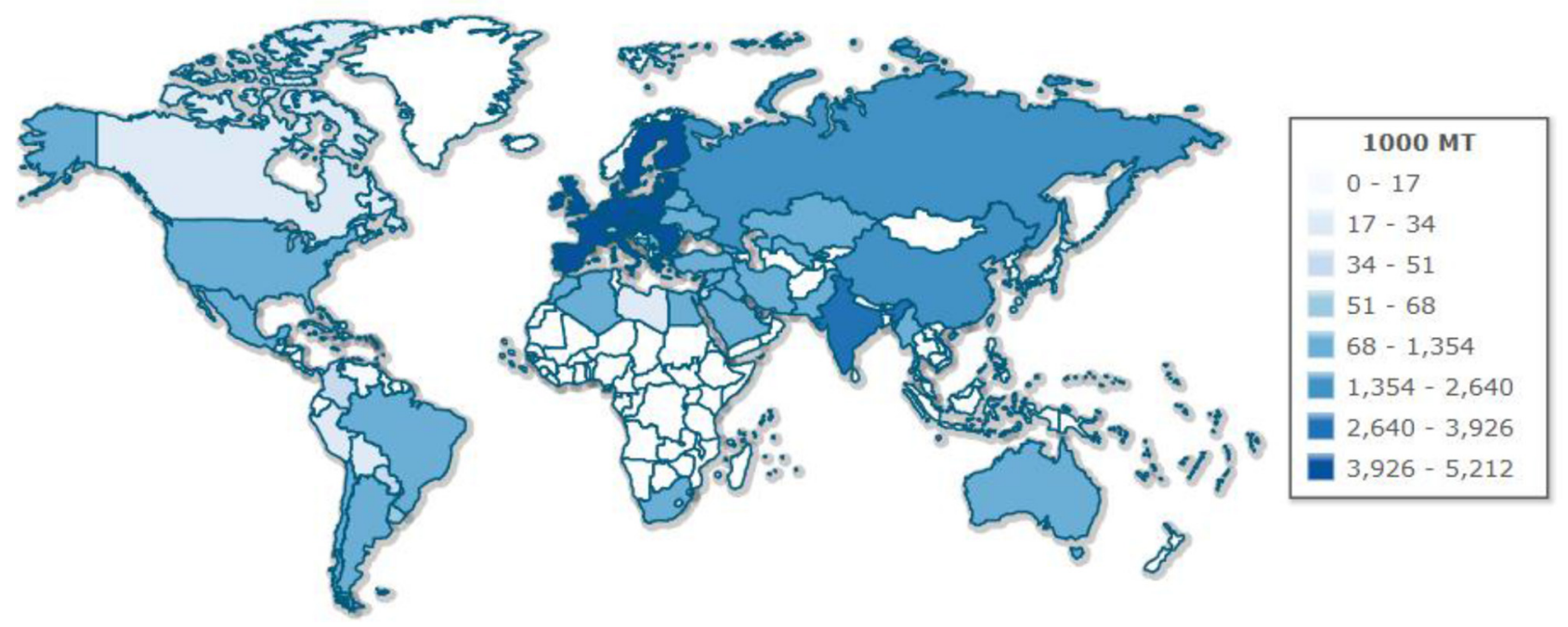

Fig. 11. Sunflower seed Oil Domestic Consumption by Country in $1000 \mathrm{MnT}$ in 2019. Source Index mundi/USDA.

Nevertheless, the progress in productivity in the leading countries is quite impressive, for most of them between 25 and $65 \%$ within 15 years, meaning between $1.4 \%$ and $3.5 \%$ annual yield increase.

\section{Global situation and dynamics of consumption}

Oil production and consumption more than doubled within the last two decades. In the same time palm oil production was multiplied by 3 , soybean oil by 2 , rapeseed oil by 1.8 and sunflower oil by 2.2 (Fig. 10).

The total oil consumption raised by $209 \%$ between 2001 and 2019 , up to $200 \mathrm{MnT} / \mathrm{year}$, much faster than the world population which raised "only" by $25 \%$ in the same period. The total growth of $105 \mathrm{MT} / \mathrm{year}$ in oil consumption on the period may be attributed for $22 \%$ to the direct effect of the population growth, $42 \%$ to the development of biodiesel production (which grew from about $1 \mathrm{MnT}$ in 2001 to $45 \mathrm{MnT}$ in 2019 (Oil World, 2019 estimates), and 36\% to changes in dietary habit and other non-food uses. These figures show the strong dynamism of the vegetable oils sector, supported by both food and non-food uses, even if the growth of production and consumption diminished at the end of the period.

Sunflower oil almost maintained its market share in this highly competitive market reshaped by the development of palm oil: after a decrease from $13 \%$ in the 1990 'ies, the market share of sunflower oil seems to be stabilized to $9-10 \%$ (Fig. 11).

\section{Trade and markets}

Oilseeds and oilseeds products present the characteristic of being highly traded commodities: Mittaine and Mielke (2012) observed that the world exports of oilcrops products (oilseeds, oils and meals) were representing $28 \%$ of the world production in 2011, much higher than most grains (Fig. 12).

If we compare the export/production ratio of the main products involved in the vegetable oils and proteins markets,

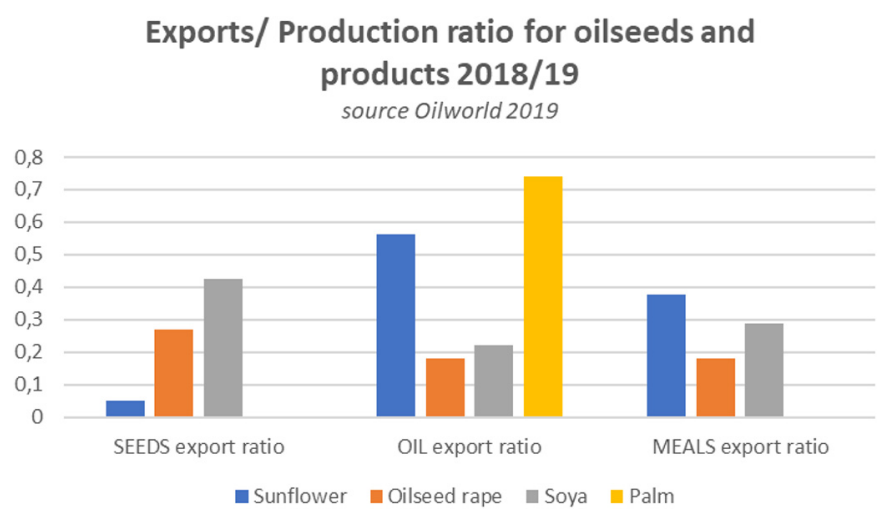

Fig. 12. Exports/production ratio for oilseeds and products.

we see that sunflower is traded mainly after processing: $55 \%$ of the oil volumes were exported in $2018 / 19,38 \%$ of the meals, and only $5 \%$ of the harvested seeds. Sunflower is transformed mainly in the countries where it is produced, which tend to keep the added value of the process. The figures are quite different for rapeseed which presents a more balanced profile between seeds, oils and meals, and soybean, for which $42 \%$ of the produced seeds are exported and oil and meals also intensively traded (20 and 28\%). The case of palm oil (exported at $70 \%$ ) is very specific with a high concentration of the production in few countries and the necessity of processing near the production sites.

This specificity of sunflower compared to other major oilseeds is that it is largely processed in the production countries. Markets characteristics and national investment strategies probably explain a part of this situation, and also the fact that sunflower seed has a relatively low density due to its hull (containing mainly low value fibres), and occupies 15 $20 \%$ larger volumes compared to other seeds (sunflower seed density ranges by 0.62 compared to 0.77 for rapeseed and wheat, and 0.74 for soybean, FAO, 2015).

Vegetable oils prices were in 2019 at a thirteen-year low in current and real terms (Fig. 13). 


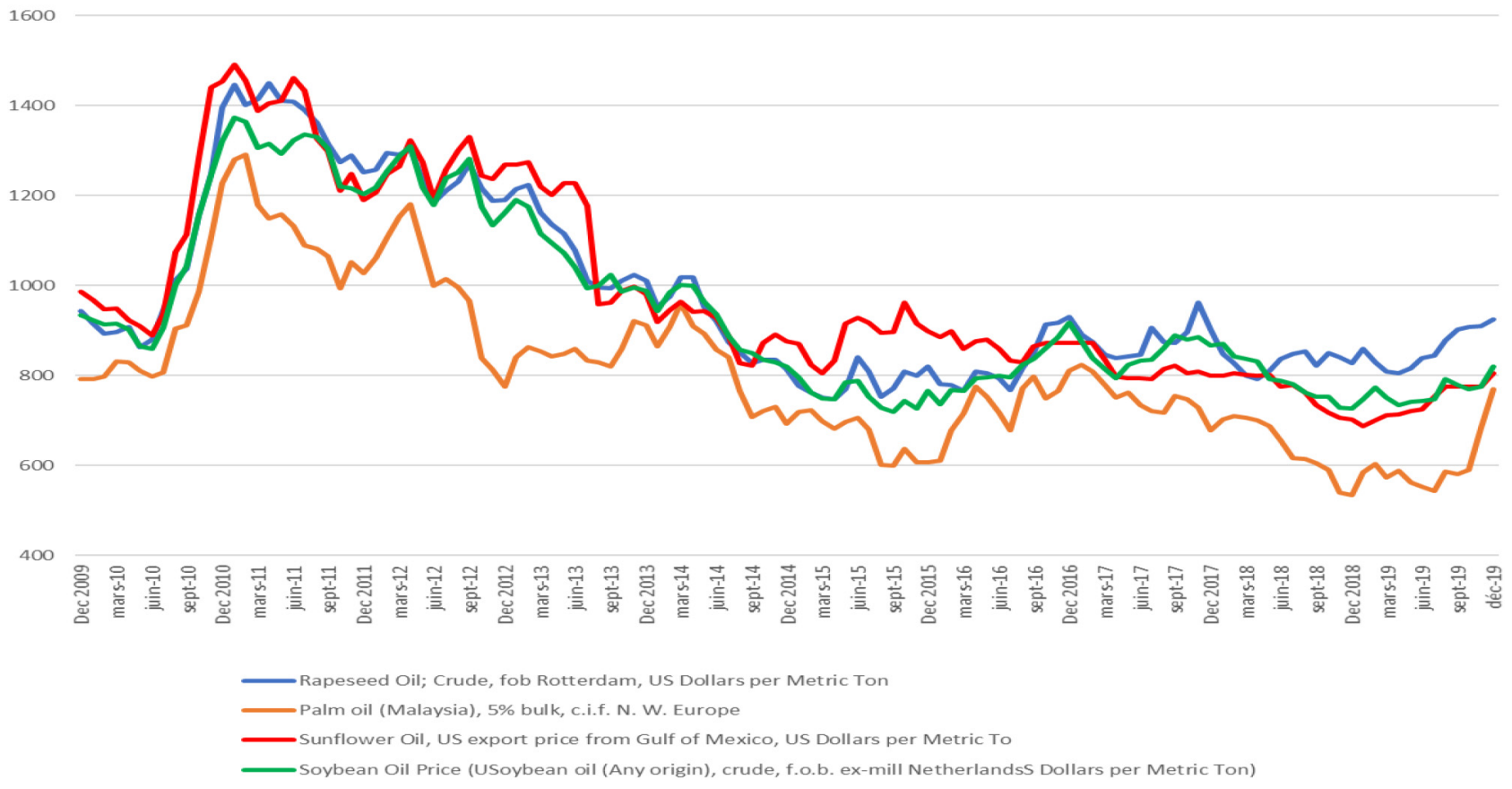

Fig. 13. 10 years vegetable oils prices evolutions.

Table 2. Annual sunflower oil imports Oct-Sept.

\begin{tabular}{lrr}
\hline & Avg. 5 years 2014-2018 MnT & $\%$ \\
\hline India & 1.85 & 18.4 \\
EU* & 1.41 & 14.0 \\
China & 0.69 & 6.9 \\
Iran & 0.36 & 3.6 \\
CIS* & 0.56 & 5.6 \\
Turkey* & 0.73 & 7.2 \\
Egypt & 0.51 & 5.0 \\
Iraq & 0.47 & 4.6 \\
Others & 2.31 & 22.9 \\
World & 10.07 & \\
\hline
\end{tabular}

*: are also exporting countries.

Source: Oil World, 2019.

Historically, sunflower oil has been considered as a premium oil and its average prices were generally significantly higher than those of soybean oil and rapeseed oil until 2016. The last 3 years show a lasting inversion of this tendency, the sunflower oil FOB NW Europe being 41 to $48 \mathrm{US} \$$ /ton cheaper than soybean oil and 104 to 185 US $\$$ cheaper than rapeseed oil (yearly average, October to September, source Oil World, 2019). It kept a premium between 30 and 130 US $\$$ compared to palm oil. This evolution seems to be largely due to the huge development of the production in Ukraine and Russia, with an increase of global sunflower oil stocks of about $27 \%$.

$75 \%$ of sunflower oil imports are bought by 8 countries (see Tab. 2). EU, CIS (mainly Ukraine and Russia) and Turkey are also exporters. The European Union is net importer of approx. $0.9 \mathrm{MnT} /$ year; CIS is net exporter of 7.7 MnT. The other main importing countries, first of all India, are structural importers, limited in their agricultural production capacities and facing demographic growth. Most of them operate shifts in the nature of their procurements, optimizing prices and origins, but sunflower oil is regularly imported, appreciated for its high quality for nutritional aspects and behaviour in frying. The case of India is interesting as it protects its internal production through imports tariffs, notably for oilseeds (mostly soybean, mustards and peanuts), but if it succeeded in maintaining a satisfying level of self sufficiency for cereals, and a lesser extent pulses, its imports of edible oils and fats almost doubled within 10 years, from $8.7 \mathrm{MnT}$ in $2008 / 09$ to $15.3 \mathrm{Mnt}$ in $2018 / 19$. Vegetable oils imports represent in value $50 \%$ of the total agri- products imports of India (Jat et al., 2019). Protection policies from a major importer may cause disturbances on edible oils markets: the slowdown in global trade observed in 2018 largely reflected the decrease in edible oils imports by India, resulting from an expansion in domestic oilseeds production - mainly rapeseed/mustard and soybean -, combined with increased import tariffs (OECDFAO, 2019).

The OECD-FAO agricultural outlook 2019-2028 considers that the vegetable oils prices should recover "due to the global expansion of food and oleochemical demands, coupled with the new domestic demand for biodiesel in selected countries, notably Indonesia", when at the same time "production constraints in major palm-oil producing countries will hamper any major expansion of supplies over the next decade, thus consolidating the upward trend of real vegetable oil prices". This global trend would benefit to sunflower oil too. 
Sunflower meals Avg 5 years 2014-2018 (Oct-Sept) in Mn tons/year. Source Oil World 2019

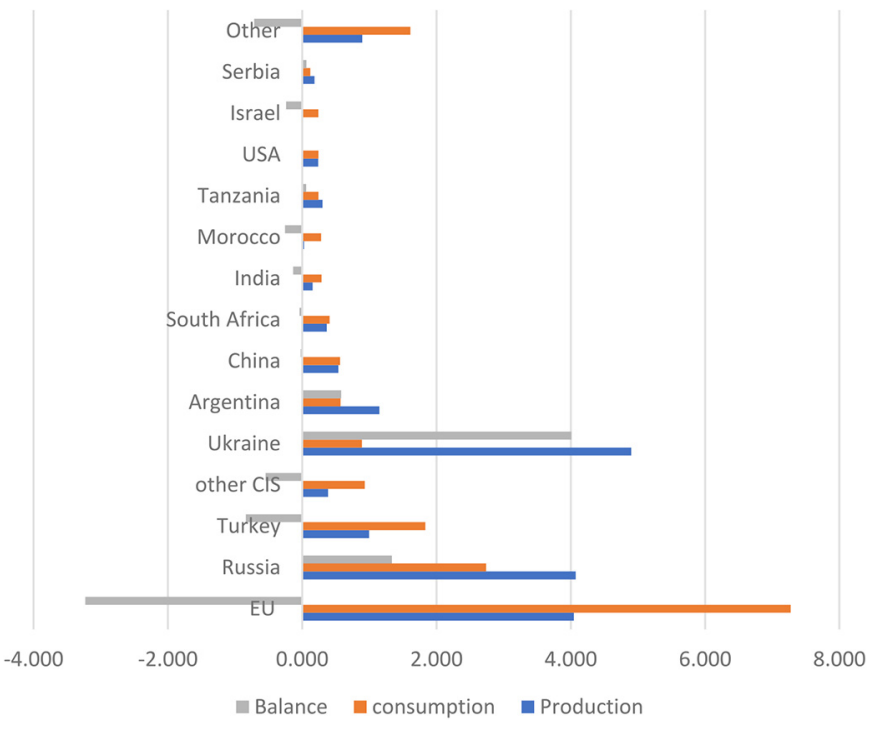

Fig. 14. Sunflower meal balances for 14 main consuming countries.

\section{Sunflower meals: the third oilseed meals in the world}

Sunflower meals are the third oilseed meal consumed in the world. The countries producing sunflower are the first consumers of sunflowers meals: $90 \%$ of the meal production is concentrated in EU, Ukraine, Russia, Argentina, Turkey, China and USA, and this group of countries consumes almost $81 \%$ of the global production; Ukraine, Russia and Argentina are the only net exporters. The EU, in spite of its high production is also the first importer. Belarus, India, Morocco and Israel are regular importers in significant quantities (Fig.14).

The classical non dehulled meal offers $29 \%$ proteins and relatively high fibres content, limiting its use to the least concentrated animal feed rations, mostly for meat bovines, sows and rabbits. This situation explains the important prices

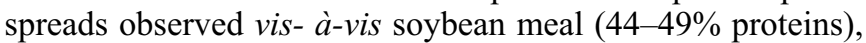
classically between 150 and $200 \mathrm{US} \$ /$ ton. Peyronnet et al. (2012) showed that the price of interest of classical sunflower meal (29\% of proteins) was $43 \%$ of soybean meal, when improved semi-hulled sunflower meal (with $32 \%$ protein) and de-hulled sunflower meal ("Hi-pro" with $36 \%$ protein) would reach $50 \%$ and $70 \%$ of the soybean value respectively. The use of sunflower hulls for energy co- generation or biomaterials makes the process profitable, contributing to the expansion of dehulled meals. The classification of feed ingredients according to their energy (AMEn cockerels) and protein values show that High Pro sunflower meal is among the best feed protein sources (Fig. 15).

\section{Sunflower and biodiesel}

The biodiesel production grew from less than $17 \mathrm{MnT}$ in 2009 to $44.8 \mathrm{MnT}$ in 2019 , expanded by 2.6 times within ten years (Oil World, 2019). However, sunflower oil has not been strongly involved in biodiesel on this decade, the major raw materials being in order of importance palm oil (17 MnT in 2019), soyabean oil (11 MnT), rapeseed oil (6.7 Mnt), tallow and reused oils (4.6 MnT). Sunflower oil is not directly involved in biodiesel, but most economists reach the conclusion that the emergence of biofuels made energy prices a driver of long-run agricultural price levels and that instability in energy markets is transferred to food markets (Serra and Zilberman, 2013). Considering the case of biodiesel alone, $44.8 \mathrm{MnT}$ represent a significant part of $48 \%$ of the global oils and fats imports and $19 \%$ of the global oils and fats consumption, and the conclusion appears consistent: strong correlations are observed between diesel prices and vegetable oils prices, up to $90 \%$ for rapeseed oil, $88 \%$ for soybean oil and $85 \%$ for sunflower oil (Communication by N. De Vore, DHF Team, at GCIRC Technical Meeting 2017, Alnarp, Sweden).

This situation for sunflower might change: according to Sofiproteol, France, 6\% of the European sunflower oil consumption would have been used in biodiesel in 2018, meaning 290 to $300 \mathrm{kT}$. Sunflower oil would represent around $2.5 \%$ of the European biodiesel production. This introduction of sunflower oil in biodiesel has probably been favoured by the recent trend of prices similar to soybean oil and even lower than rapeseed oil, and by the favourable environmental life cycle assessment of sunflower oil, similar to or better than that of rapeseed oil as shown by J.-H. Schmidt (Schmidt, 2015) whose calculations are made on the basis of a seed yield of $1.67 \mathrm{t} / \mathrm{ha}$. In this study, the main sunflower weakness regarding life cycle assessment is land occupation, due to this relatively low yield level. Calculations in French conditions confirm this tendency and show that sunflower oil methyl esters present lower greenhouse gas emissions compared to other oil methylesters (BIO IS 2010 study, cited by Debaeke et al., 2017). These figures still offer margins of progress and make sunflower good candidate for sustainable biodiesel standards. If this shift confirms, sunflower could be directly involved in biodiesel market.

\section{Oleic sunflower}

High oleic sunflower contains 4 times more oleic acid than classical sunflower, with $84 \%$ oleic acid in oil. It competes on global scale with other high oleic oils but has the highest oleic level compared to oleic safflower $(78 \%)$, oleic rapeseed and canola (75-73\%) and oleic soybean (73\%) (Tonin, 2018). The oleic market is pulled by the demand of food and catering industries, as an alternative to trans-fats presenting good technological properties (relatively long life, stability to temperature), with low saturated fats. The EU market in 2018 was $20 \%$ oleic and $80 \%$ classical sunflower.

In 2019 , the oleic production ranges by $3.8 \mathrm{MnT}$, i.e. $7 \%$ of the global sunflower production. For almost 20 years, France has been a pioneer regarding oleic sunflower, more than $60 \%$ of its production being converted to oleic varieties since 2010 , reaching $76 \%$ in 2019 . The production of oleic sunflower grew quickly in Ukraine and Russia, reaching $420 \mathrm{Kha}$ in 2018 (Tonin, 2018) and will probably quickly overpass the acreage in Western Europe. This boost in production shake up the premiums for oleic sunflower and their regularity. 


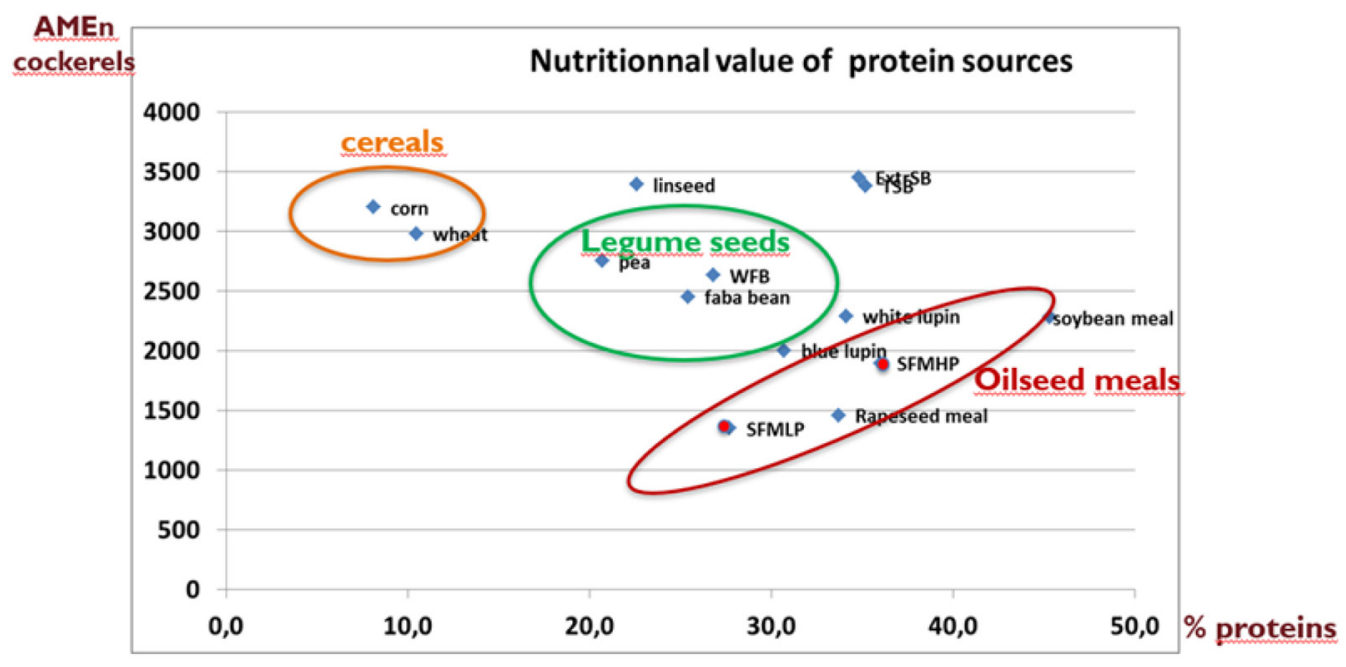

From INRA, FEEDIPEDIA

(AMEn :Apparent Metabolizable Energy for cockerels, nitrogen corrected)

Fig. 15. Feed protein sources: high pro sunflower meals among the best (Source: Terres Univia) SFMHP: Sunflower Meal high Pro; SFMLP: Sunflower Meal Low Pro.

The non-GMO nature of oleic sunflower varieties gives them a competitive advantage over oleic canola or soybean oils on the European market, even if we have to keep in mind that it could be challenged by the controversies in Europe regarding the varieties obtained through mutagenesis - often for herbicides tolerance characters - and the positions of the European Court of Justice (July 25, 2018), assimilating the varieties obtained with the most recent mutagenesis techniques to "GMO", i.e. originally transgenesis. On the other hand, the development of the use of cheaper oil blends - with lower oleic content - by the industries reduces the competitive advantage conferred by the highest oleic content of sunflower oleic oils. For the time being, the oleic sunflower seeds may be considered as a commodity in France and still a niche market in most other countries, and the still low rate of oleic sunflower in these countries reflects a high potential of development. The main uncertainty is the evolution of the oleic market for food industries and catering outside Europe and North America, where food safety and nutritional properties correspond to a real and growing demand from consumers: oleic sunflower is, at first, the best alternative to palm oil with similar stability and the advantage of reducing the saturated fats content, but is more expensive and food industries optimize their formulas according to consumers' demand and to regulations. However, HOLLI sunflower has certainly a brilliant future over the world.

\section{Developing market: confectionery sunflower}

Confectionery sunflower is another trend in sunflower market segmentation, and specific breeding efforts are also needed to meet the diversified demand of this market, taking into account national preferences as explained by N. Hladni and D. Miladinović (Hladni and Miladinović, 2019). These
Confectionery sunflower seeds consumption 2013/2017 Source Qiaqia Food Cy 2018; in 1000 tons

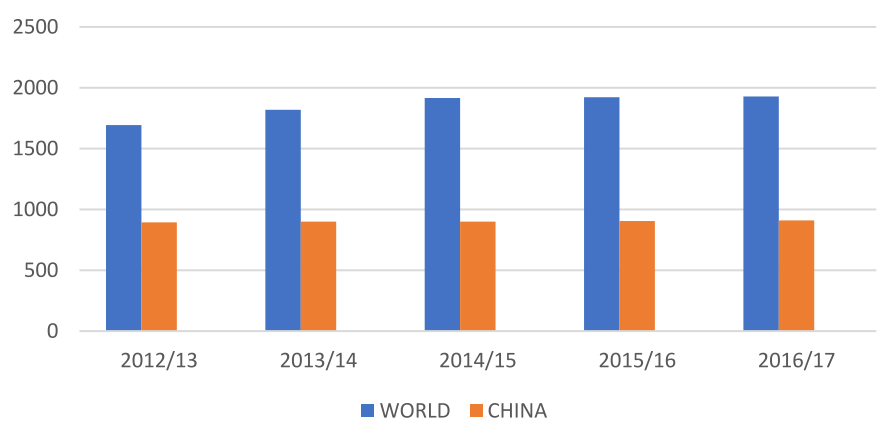

Fig. 16. Confectionery sunflower seeds consumption.

seeds are used inshell for snacks, as roasted or/and salted seeds, or hulled, mainly for bakery.

Confectionery sunflower is not identified in statistics but presents the particularity, with seeds for bird husbandry and pets, of not being crushed. Some figures (Fig. 16) have been provided for the food market of snack seeds and bakery during the Symposium on Confection Sunflower technology and Production, held in Wuyuan, China, in August 2018, by the Chinese Qiaqia Food Company, as reported by the International Sunflower Association newsletter dated March 2019 , showing that this market is slowly expanding with specific demands, the task of the industry being "to meet the demand for new forms of retailing and innovation in flavors". China alone would represent almost half of the market (Fig. 16).

If we compare this information with the category "other uses" of the yearly world sunflower balance (Tab. 3), we may estimate that confectionery types would represent at least $40 \%$ of these "other uses", and 4\% of the global sunflower production: a significant segment with specific added value. 
Table 3. World supply and demand MT (Source: Oil World, 2019).

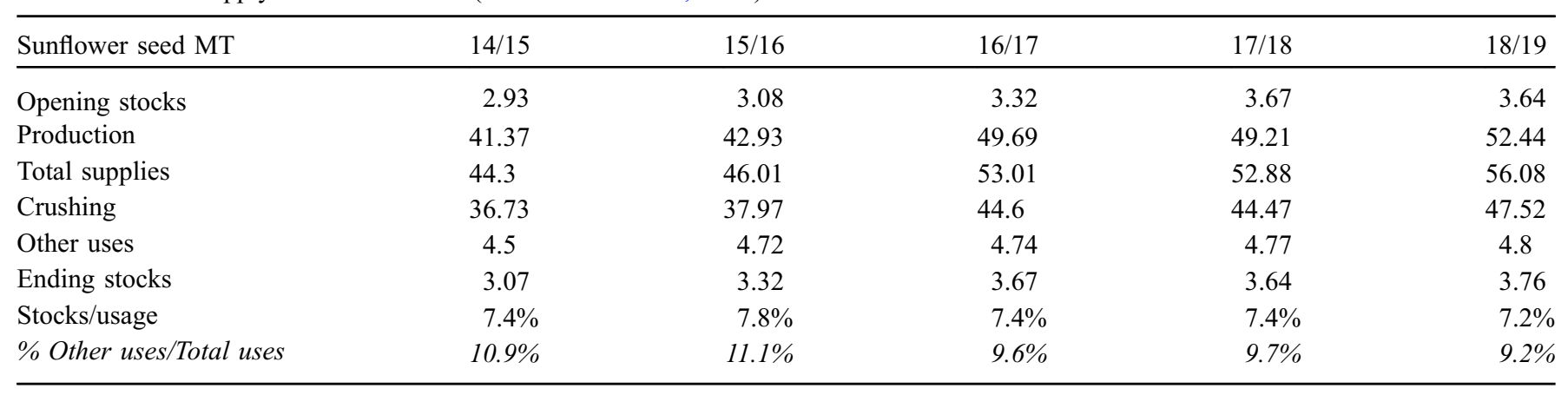

Most of the major sunflower producing countries are concerned by confectionery types: China, Turkey, Ukraine, Russia, Eastern part of EU and USA.

Breeding objectives for seeds quality are very specific, notably with higher protein content and lower oil, and seeds size, shape, colour and hulling criteria. The development of a specific selection for confectionery types seems to face a limited genetic diversity and require collaboration in exchanging sunflower lines to support the creation of hybrids with improved yields levels, agronomic characteristics and nutritional quality for proteins and minor components. Improving genetics will be a necessity to support a full development of this market. The protein challenge could be common to confectionery and oil types and could benefit from common works.

At last, new development on this market is susceptible to bring about evolutions in the consumers perception of sunflower crop.

\section{Questions for future: perspectives, challenges}

The future of sunflower must be considered in a much wider system than only sunflower production and markets: the whole world agriculture and food system, whose main drivers are demography, evolutions in dietary habits, especially animal products consumption (related to welfare and economic growth), and evolutions of agricultural productivity and resources availability (land, water, nutrients), which will be largely influenced by the rapidity and intensity of climate change (Pilorgé and Muel, 2016, foresight for plant oils and proteins). What could be the advantages and weaknesses of sunflower in future, in relation to what opportunities and threats?

Many foresight studies have been carried out for some years, and most of them converge on the importance of the protein challenge, either seen as a quantitative challenge "to feed the world" or as a room for manoeuvre, a key factor to limit the impact of food consumption on environment by diminishing the consumption of animal protein to the benefit of vegetal proteins, demanding much less resources. The figures emerging from the calculations notably in terms of supplementary agricultural land availability, are generally impressive and let think that the answers for proper adaptations will be multiple, involving both progress in animal nutrition and a larger use of vegetal proteins in human regimes, notably in the countries were animal proteins are dominant and even overconsumed compared to nutritional recommendations (Americas, Western Europe, China...). On the other hand, a part of world, notably Africa, would need to increase its protein consumption (of either vegetable or animal origin) to reach the level of nutritional recommendations.

In this respect, the improvement of sunflower meals on their protein content represent a technical progress for animal feed and in the perspective of protein extraction for food industries, and a much wider field of innovation is open to valorise the sunflower proteins directly for human food, from genetic improvement to technological innovation and evolutions in consumption through marketing initiatives. Sunflower has the double advantage to be already currently used for food in bakery, snacks, etc... and to be non-GMO. If the non-GMO nature is of limited interest for oils, it is a key characteristic for the use of proteins for food. In Europe, the consumption of GMO is admitted for feed but not for food, and the recent tendency is even a demand for animal products guaranteed non-GMO fed. The share of non-GMO certified feed was $13 \%$ (and 2\% organic) in France in 2017 and could reach 18 to 30\% in the coming years. This evolution is not limited to France, which is not pioneer in this domain in Europe.

There is no doubt on the interest of developing added value from the protein fraction, which seems to be a real opportunity for sunflower. Knowledge (characterization of nutritional and technological properties of sunflower proteins) and technological developments will be needed.

The valorisation of the oil fraction has been challenged for 20 years by the rapid development of palm in Indonesia and Malaysia, which put pressure on vegetables oils prices since the growth of palm oil volumes was much faster than the evolution of edible oils demand. The more "optimistic" hypotheses about palm development led to imagine an ocean of oil scenario with durable low prices for vegetable oil. Nevertheless, vegetable oils are highly valuable products for industry, able to substitute petroleum in chemistry with noticeable advantages regarding sustainability, as renewable resources and biodegradable products. In recent periods, the vegetable oil prices did not collapse, partly due to specific biofuel policies in the producing countries: on the last decade (2011-2019), the biodiesel production (based on non-recycled oils) absorbed the equivalent of $71 \%$ of the increase in palm oil production, or $32 \%$ of the increase in all vegetable oils production and contributed in maintaining prices, and also creating a link with energy prices. 
In the coming years, the growth in palm oil production might be slower than initially expected, due to the necessity to renew old plantations, and the replantation dynamic will be influenced by the market itself and notably by more or less incentive policies in Indonesia and Malaysia, and the development of specific demands on sustainability in the European Union. According to Sofiproteol (communication at International Rapeseed Congress, Berlin June 2019), a slow replantation scenario would lead to a production of $79 \mathrm{MnT}$ of palm oil in 2030, compared to $59 \mathrm{MnT}$ in 2018 and 70 in 2020, and a fast replantation scenario to $90 \mathrm{MnT}$ in 2030 , with a phase of stagnation - if not decline - between 2020 and 2025 , and then recovery. To summarize, the growth of palm oil production would range between 20 and $30 \mathrm{MnT}$ until 2030. In the same period to 2030 the trend for edible oil consumption, due to the population growth and diets evolutions, would be to a growth of about $2 \%$ /year, i.e. +25 to $30 \mathrm{MnT}$ depending on scenarios. These figures tend to divert out of an "ocean of oil" scenario, even if also soybean oil has to be taken into account as a co-product of soybean meal, which will certainly go on growing to meet the demand of the animal feed sector.

Another element could play on vegetable oil consumption: non-food uses for oleochemistry. We know that the development of oleochemistry is highly dependent on petroleum prices competition, but also on regulations and policies which could favour a series of small markets on sustainability or biodegradability criteria. And innovation will probably meet this developing demand: a communication by Isso Noda of Danimer Scientific (USA) at the Canola Innovation Day in December 2019, Saskatoon, Canada, reported a new process for making bioplastics from vegetable oils, based on bacterial fermentation and potentially competitive with classical petroleum plastics. This project is under upscaling. This kind of development might boost the potential added value in nonfood uses, progressively relay the 1 st generation biodiesel and contribute in sustaining vegetable oils markets.

The average level of vegetable oils markets will not depend on sunflower, but sunflower oil keeps specific advantages regarding nutritional quality and technological properties which should allow it to maintain its position among premium oils.

In a "biorefinery" perspective, the cellulosis fraction should also be considered: the technologies are ready to valorise sunflower stem fibres and pith in biomaterial such as particle boards or insulating materials from renewable sourcing. The limiting factors actually is the cost of collection and logistics.

Concerning agronomy and cropping practices, the past evolutions of yield levels in different conditions demonstrate the adaptation capacity of sunflower but also that the yield gap - actual results compared to genetic potential - is still high and that yield progress can still be expected. Its relatively low demand in nitrogen fertilizer and relative adaptability to drought stress made its reputation of "rusticity", and its low dependence on phytochemicals, resulting of continuous investments in genetic tolerance to diseases, will be strengths in more frugal systems regarding synthetic inputs or scarce resources such as nutrients or water.

With regard to climate change, the review by Debaeke et al. (2017) concluded for Europe, that sunflower could improve in Northern latitude but be affected negatively on medium term in Southern and Eastern Europe if proper adaptation of cropping practices and cultivars is not achieved, even if "the $\mathrm{CO}_{2}$ fertilization effect could compensate the negative impacts of high temperatures, water stress and reduced crop duration". The possibility to rely on a diversity of cultivars differing on their rusticity/productivity behaviour (notions of "conservative" or "productive" profiles) will be important for adaptation.

\section{Conclusions}

Sunflower succeeded in maintaining its competitiveness on oilseeds markets in the previous decades, through continuous innovation in genetics, production and markets and a growing segmentation. Many opportunities could be open in future for sunflower, leading to an increased valorisation of the whole plant through a biorefinery approach and a diversification of uses of oil (for food, food industry, biofuels, biomaterials), proteins (for feed, including aquaculture, food, potentially biomaterials), and even cellulosic fraction. The plasticity of sunflower makes it a crop relatively adaptable to different kinds of agricultural policies and resulting agricultural systems. The dilemma will be as always in the repartition of research and innovation efforts towards different and multiple objectives, this issue being reinforced by the higher market segmentation. Coordination and collaboration are not new concepts in the world of sunflower science, and more important than ever.

\section{References}

Debaeke P, Casadebaig P, Flenet F, Langlade N. 2017. Sunflower crop and climate change: vulnerability, adaptation, and mitigation potential from case- studies in Europe. OCL 24(1): D102. https:// doi.org/10.1051/ocl/2016052.

FAO. 2015. Base de données FAO/INFOODS sur la densité. Version 2.0 (2015). Document élaboré par U. Ruth Charrondiere, D. Haytowitz, B. Stadlmay. http://www.fao.org/3/a-i3057f.pdf.

Hladni N, Miladinović D. 2019. Confectionery sunflower breeding and supply chain in Eastern Europe. OCL 26-29. https://doi.org/ $10.1051 / \mathrm{ocl} / 2019019$.

ISA Newsletter No3. 2019. http://isasunflower.org/news/single-view/ article/newsletter-3-march-2019.html.

Jat RS, Singh VV, Sharma P, Rai PK. 2019. Oilseed brassica in India: Demand, supply, policy perspective and future potential. OCL 26 (8). https://doi.org/10.1051/ocl/2019005.

Mittaine J- F., Mielke T. 2012. The globalization of international oilseeds trade. OCL 19(5). https://dx.doi.org/10.1051/ ocl.2012.0470.

OECD- FAO. 2019. Agricultural outlook 2019-2028, chapter 4, Oilseeds and oilseed products.

Oil World Annual. 2019. Vol. 1. Global analysis of all major oilseeds, oils and oilmeals: Supply, demand and price outlook. ISTA Mielke Gmbh, May 2019.

Peyronnet C, Pressenda F, Quinsac A, Carré P. 2012. Impact du décorticage du tournesol sur la valeur nutritionnelle et l'intérêt économique des tourteaux en fabrication d'aliments composés. OCL 19: 341-346. https://doi.org/10.1051/ocl.2012.0486 . 
Pilorgé E, Muel F. 2016. What vegetable oils and proteins for 2030? Would the protein fraction be the future of oil and protein crops? OCL 23(4): D402. https://doi.org/10.1051/ocl/2016030.

Sarron J, Brun F, Casadebeig P, Rollet P, Mestries M, Debaeke P. 2016. Diagnostic agronomique des évolutions des rendements du tournesol en France. UMT Tournesol \& GIS GCHP2E.

Schmidt JH. 2015. Life cycle assessment of five vegetable oils. $J$ Clean Prod 87: 130-138. https://dx/doi.org/10.1016/j.jcle pro.2014.10.011.
Serra T, Zilberman D. 2013. Biofuel related price transmission literature: a review. Energy Econ 37: 141-151. http://dx.doi.org/ 10.1016/j.eneco.2013.02.014.

Tonin P. 2018. Les productions françaises d'oléagineux de spécialité : des démarches en filière pour créer de la valeur dans nos territoires. OCL 25(2): D203. https://doi.org/10.1051/oc1/2018015.

Vear F, Muller MH. 2011. Progrès varietal chez le tournesol : l'apport des ressources génétiques au sein du genre Helianthis. Innov Agron 14: 130-150.

Cite this article as: Pilorgé E. 2020. Sunflower in the global vegetable oil system: situation, specificities and perspectives. OCL 27: 34. 